\title{
Comparison of Wet Process and Dry Process of Cement Manufacturing with Advantages and Disadvantages
}

\author{
Ms. Elena Rosemaro \\ VIM Australia \\ elenarosemaro@gmail.com
}

Abstract

In this paper we are discussing wet and dry process of Portland cement manufacture. Wet process minerals are wet ground to form a slurry and in dry process minerals are dry ground to form a powder like substance. In this paper, we are discussing the comparison between wet process and dry process with various advantages and disadvantages.

Keywords: Portland cement, slurry, lime stone etc.

\section{INTRODUCTION}

There are two types of process for manufacturing the cement are shown in below.

\section{Wet process}

Raw materials are mix in wash mill by 35 to $50 \%$ water. The current Materials are known as slurry that have flow-ability features. The kiln size that are required for built-up of cement is higher so the raw material can be mixed effortlessly that's why well similar type of material can be acquired. The production cost of wet process is high and capital cost is relatively less. 


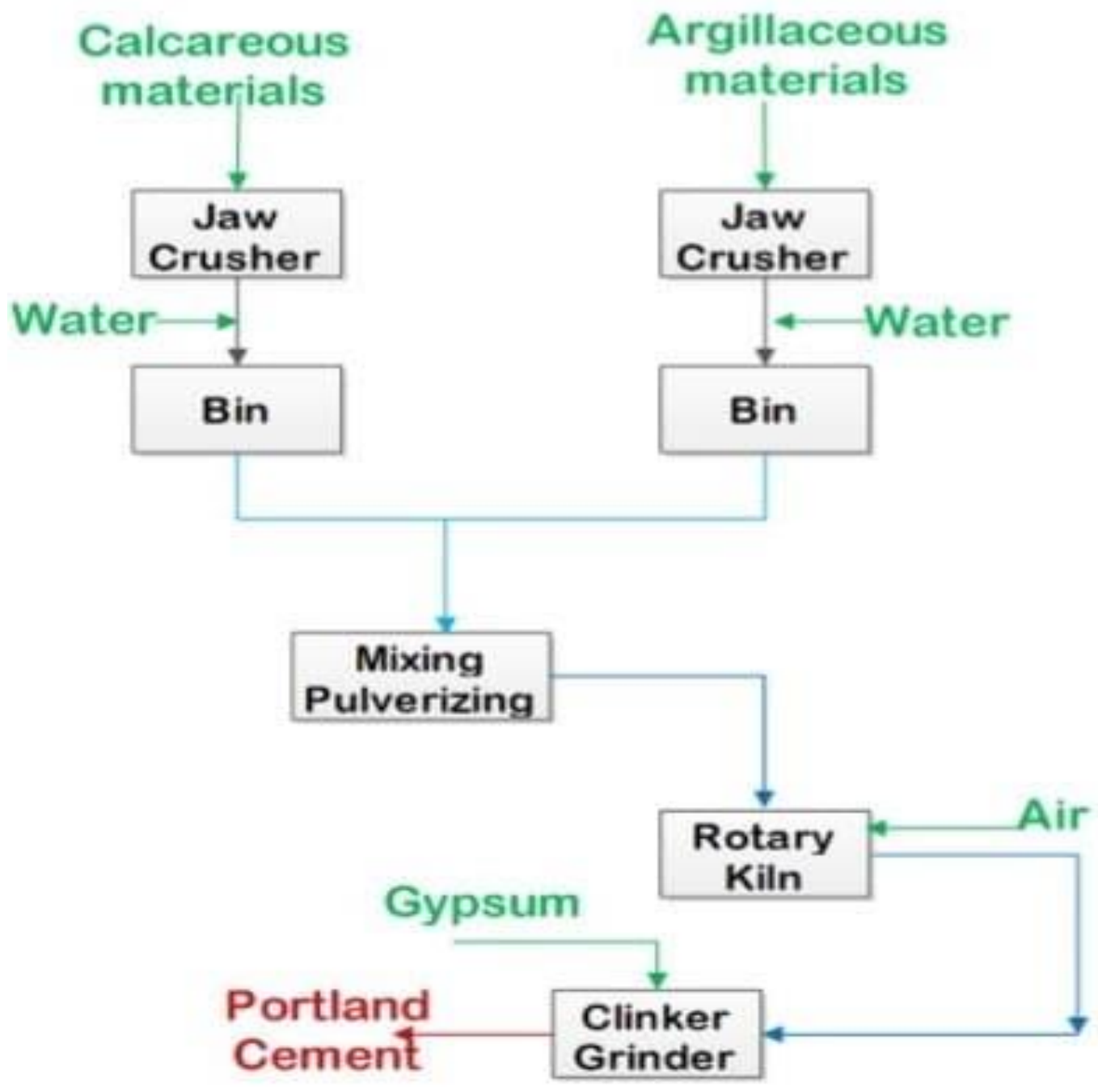

Fig 1: Manufacture of Cement by Wet Process

\section{Dry process}

In the dry process, raw material is mixes in mixers. This dry materials also known as kiln feed. The kiln size are required for built-up of cement is smaller so it is difficult to control Raw materials mixing and it is also challenging to find a well similar material. The production cost is less and capital cost is relatively high because of blender. 


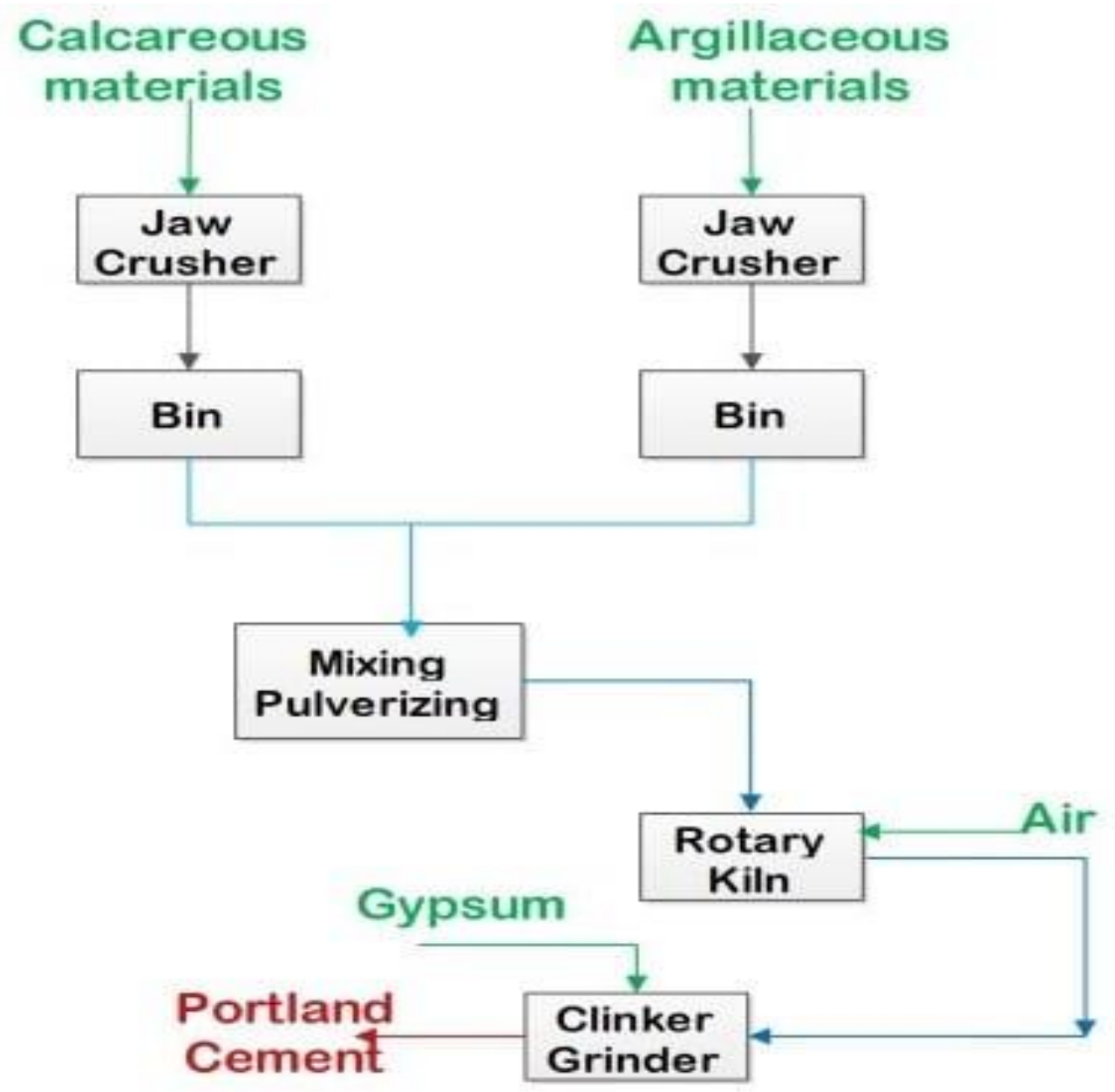

Fig: Manufacture of Cement by Dry Process

Table 1

Raw materials for Portland cement manufacture 


\begin{tabular}{|c|c|c|c|}
\hline $\begin{array}{c}\text { Calcareous } \\
\text { Materials }\end{array}$ & \multicolumn{3}{|c|}{ Argillaceous Materials } \\
\hline Calcium & Silicon & Aluminum & Iron \\
\hline Limestone & Clay & Clay & Clay \\
\hline Marl & Marl & Shale & Iron ore \\
\hline Calcite & Sand & Fly ash & Mill scale \\
\hline Aragonite & Shale & Aluminum ore refuse & Shale \\
\hline Shale & Fly ash & & Blast furnace dust \\
\hline Sea Shells & Rice hull ash & & \\
\hline Cement kiln dust & Slag & & \\
\hline
\end{tabular}

II. DIFFERENCE BETWEEN DRY PROCESS AND WET PROCESS

\begin{tabular}{|c|c|c|}
\hline S.no. & Wet process & Dry process \\
\hline 1. & $\begin{array}{c}\text { When raw material is soft then this method is } \\
\text { used }\end{array}$ & $\begin{array}{c}\text { When raw material is hard then this } \\
\text { method is used }\end{array}$ \\
\hline 2. & $\begin{array}{c}\text { The raw material are changed to powdered } \\
\text { form in the presence of water }\end{array}$ & $\begin{array}{c}\text { The raw material are changed to } \\
\text { powdered form in the of absence } \\
\text { water }\end{array}$ \\
\hline 3. & cement produced-26\% & kement produced-74\% \\
\hline 4. & kilns high fuel needed & More Economically \\
\hline 5. & Less Economically & Need of maintenance is high \\
\hline 6. & Need of maintenance is less & Raw material cannot be easily mix \\
\hline 7. & Raw material can be easily mix & Production cost less \\
\hline 8. & Production cost high & Capital cost is less \\
\hline 9. & Capital cost is less & \\
\hline
\end{tabular}




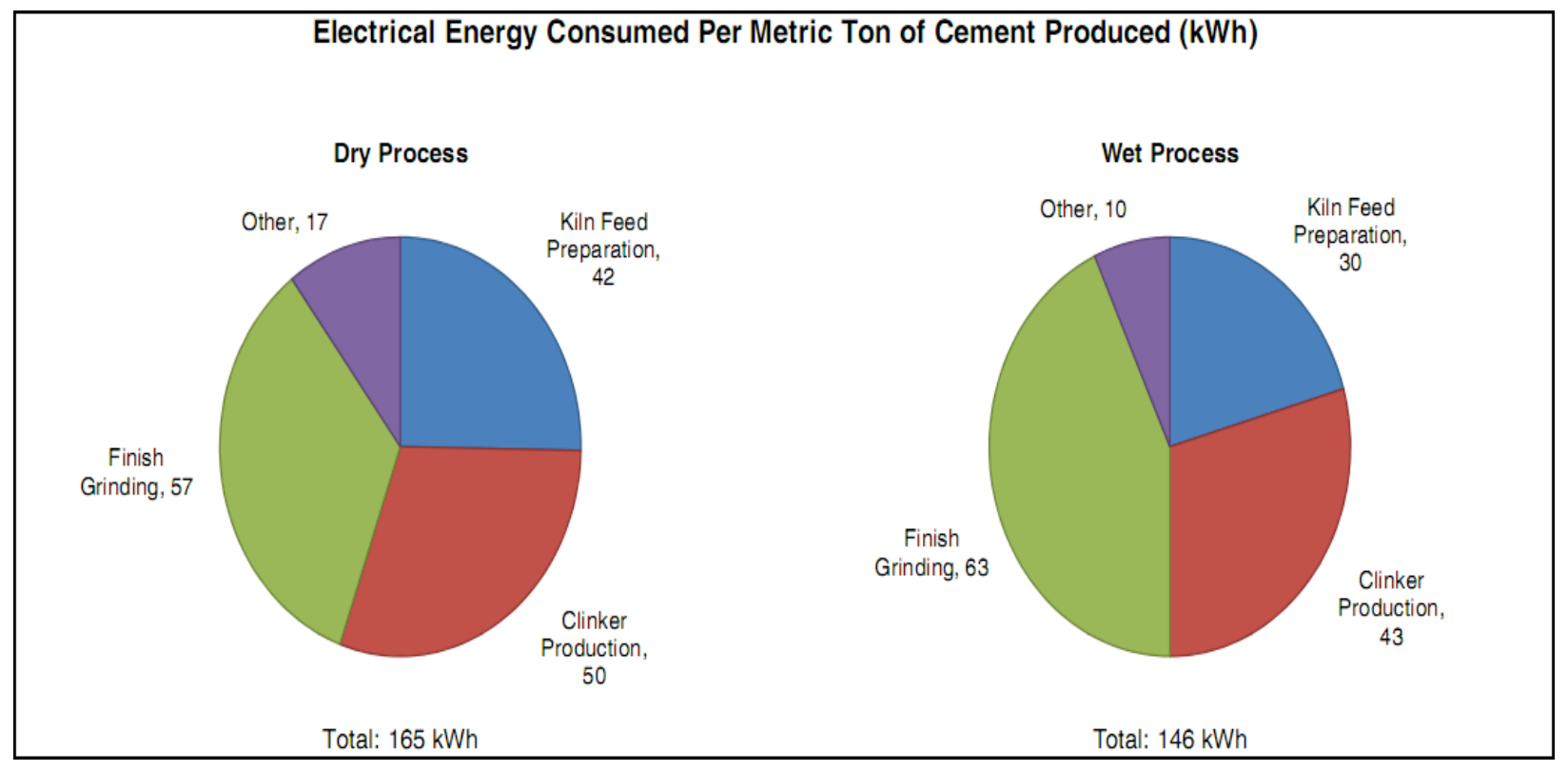

Fig 3: Electrical energy consumed by both process

\section{CONCLUSION}

In this paper we have discussed about the wet and dry cement manufacturing process. And also we have discussed about various raw materials for Portland cement manufacture. This paper shows the comparison between wet process and dry process with various advantages and disadvantages.

\section{REFERENCES}

[1] C. M. Hanson, "Concrete: the advanced industrial material of the 21st century," Metallurgical \& Materials Transactions A, vol. 26, pp. 1321-1341, 1995.

[2] M. Bediako, S. K. Y. Gawu, and A. A. Adjaottor, "Suitability of some Ghanaian mineral admixtures for masonry mortar formulation," Construction and Building Materials, vol. 29, pp.

667-671, 2012.

[3] S. H. Kosmatka, B. Kerkhoff, and W. C. Panarese, Design and Control of Concrete Mixtures, Portland Cement Association,Skokie, Ill, USA, 14th edition, 2002.

[4] M. S. Mamlouk and J. P. Zaniewski, Materials for Civil andConstruction Engineers, Prentice Hall, Upper Saddle River, NJ,USA, 2006.

[5] T. Punmatharith, M. Rachakornkij, A. Imyim, and M.Wecharatana, "Co-processing of grinding sludge as alternative raw material in portland cement clinker production," Journal

of Applied Sciences, vol. 10, no. 15, pp. 1525-1535, 2010. 
[6] D. N. Huntzinger and T. D. Eatmon, "A life-cycle assessment of Portland cement manufacturing: comparing the traditional process with alternative technologies," Journal of Cleaner Production, vol. 17, no. 7, pp. 668-675, 2009.

[7] F. M. Lea, The Chemistry of Cement and Concrete, Arnold Publishers, London, UK, 3rd edition, 1970.

[8] J. F. Young, S.Mindess, R. J. Gray, andA. Bentur,TheScience andTechnology of Civil Engineering Materials, Prentice-Hall, Upper Saddle River, NJ, USA, 1998.

[9] H. F. W. Taylor, Cement Chemistry, Thomas Telford, London,UK, 2nd edition, 1997.

[10] S. H. Kosmatka and M. L. Wilson, Design and Control of Concrete Mixtures, Portland Cement Association, Stokie, Ill, USA, 2011.

[11] V. Sata, C. Jaturapitakkul, and K. Kiattikomol, "Influence of pozzolan from various by-product materials on mechanical properties of high-strength concrete," Construction and BuildingMaterials, vol. 21, no. 7, pp. 1589-1598, 2007.

[12] A. Neville, Neville on Concrete, ACI, Farmington Hills, Mich, USA, 2003.

[13] R. Fernandez, F. Martirena, and K. L. Scrivener, "The origin of the pozzolanic activity of calcined clay minerals: a comparison between kaolinite, illite and montmorillonite," Cement and

Concrete Research, vol. 41, no. 1, pp. 113-122, 2011.

[14] K. Ganesan, K. Rajagopal, and K. Thangavel, "Evaluation of bagasse ash as supplementary cementitious material," Cement and Concrete Composites, vol. 29, no. 6, pp. 515-524, 2007.

[15] S. Sinthaworn and P. Nimityongskul, "Quick monitoring of pozzolanic reactivity of waste ashes," Waste Management, vol.29, no. 5, pp. 1526-1531, 2009.

[16] J. J. Brooks,M. A.M. Johari, andM.Mazloom, "Effect of admixtures on the setting times of highstrength concrete," Cement and Concrete Composites, vol. 22, no. 4, pp. 293-301, 2000.

[17] X. Fu, Z.Wang,W. Tao et al., "Studies on blended cement with a large amount of fly ash," Cement and Concrete Research, vol. 32,no. 7, pp. 1153-1159, 2002.

[18] E.-H. Kadri, S. Kenai, K. Ezziane, R. Siddique, and G. De Schutter, "Influence of metakaolin and silica fume on the heat of hydration and compressive strength development of mortar," Applied Clay Science, vol. 53, no. 4, pp. 704-708, 2011. 